\title{
FEATURE Impacts of 2011 Len Small levee breach on private and public Illinois lands
}

\author{
Kenneth R. Olson and Lois Wright Morton
}

A griculture, the dominant land use of the Mississippi River Basin for more than 200 years, has substantively altered the hydrologic cycle and energy budget of the region (NPS 2012). Extensive systems of US Army Corps of Engineers (USACE) and private levees from the Upper Mississippi River near Cape Girardeau, Missouri, southward confine the river and protect low-lying agricultural lands, rural towns, and public conservation areas from flooding. The Flood of 2011 severely tested these systems of levees, challenging public officials and landowners to make difficult decisions, and led to extensive damage to crops, soils, buildings, and homes. One of these critical levees (figure 1), the Len Small, failed, creating a $1,500 \mathrm{~m}(5,000 \mathrm{ft})$ breach (figure 2$)$ where fast-moving water scoured farmland, deposited sediment, and created gullies and a crater lake. The Len Small levee, built by the Levee and Drainage District on the southern Illinois border near Cairo to protect private and public lands from 20-year floods, is located between mile marker 21 and mile marker 35 (figure 1). It connects to Fayville levee that extends to Mississippi River mile marker 39, giving them a combined length of $34 \mathrm{~km}(22 \mathrm{mi})$ protecting 24,000 ha $(60,000 \mathrm{ac})$ of farmland and public land, including the Horseshoe Lake Conservation area. The repair of the breached levee, crater lake, gullies, and sand deltas began in October of 2011 and continued for one year.

\section{HISTORICAL GEOLOGICAL FEATURES OF THE WESTERN ALEXANDER COUNTY}

The Mississippi River is a meandering river of oxbows and cutoffs, continuously eroding banks, redepositing soil, and changing paths. Its willful historic meandering is particularly apparent in western

Kenneth R. Olson is professor of soil science in the College of Agricultural, Consumer, and Environmental Sciences, University of Illinois, Urbana, Illinois. Lois Wright Morton is professor of sociology in the College of Agriculture and Life Sciences, lowa State University, Ames, lowa.

\section{Figure 1}

Map of Alexander County, Illinois, including the Len Small levee and the northern part of the Commerce to Birds Point levee, Missouri, areas.

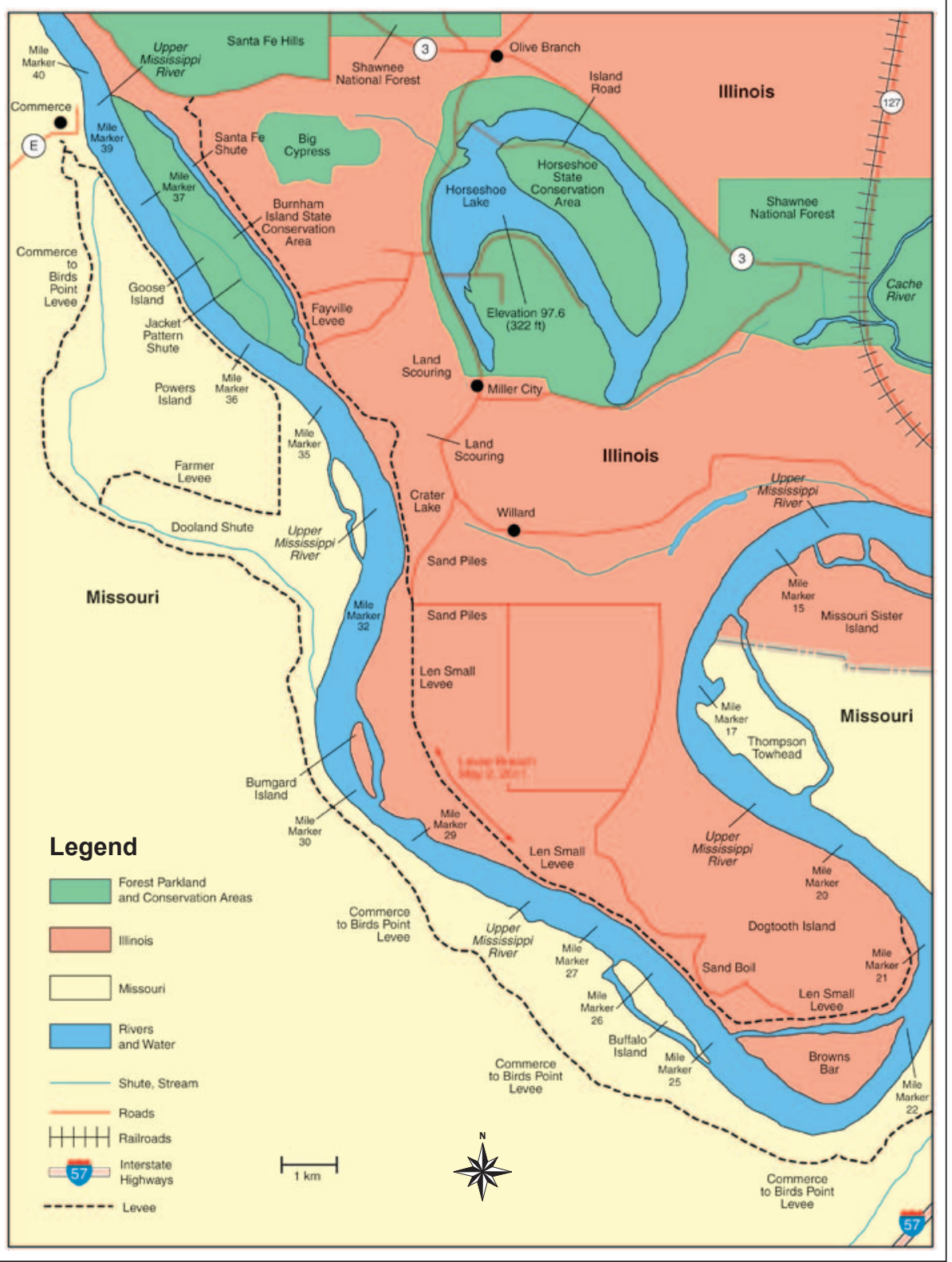

Alexander County, Illinois, where a topographical map shows swirls and curves and an oxbow lake, Horseshoe Lake, where the river once flowed south of Thebes and east of the modern day Len Small levee. The loess-covered upland hills (Fehrenbacher et al. 1986) of the Shawnee National Forest just north of Route 3 (figure 1) give way to a low-lying plain between the Mississippi and Ohio rivers. The ancient Ohio River drained through the Cache River valley during the Altonian and Woodfordian glacial advances $(60,000$ to 30,000 years B.P.) and converged with the Mississippi River waters just northwest of Horseshoe Lake. The Cache River valley is $3 \mathrm{~km}(1.9$ mi) wide and carried a substantive flow of water from the eastern Ohio River Basin 


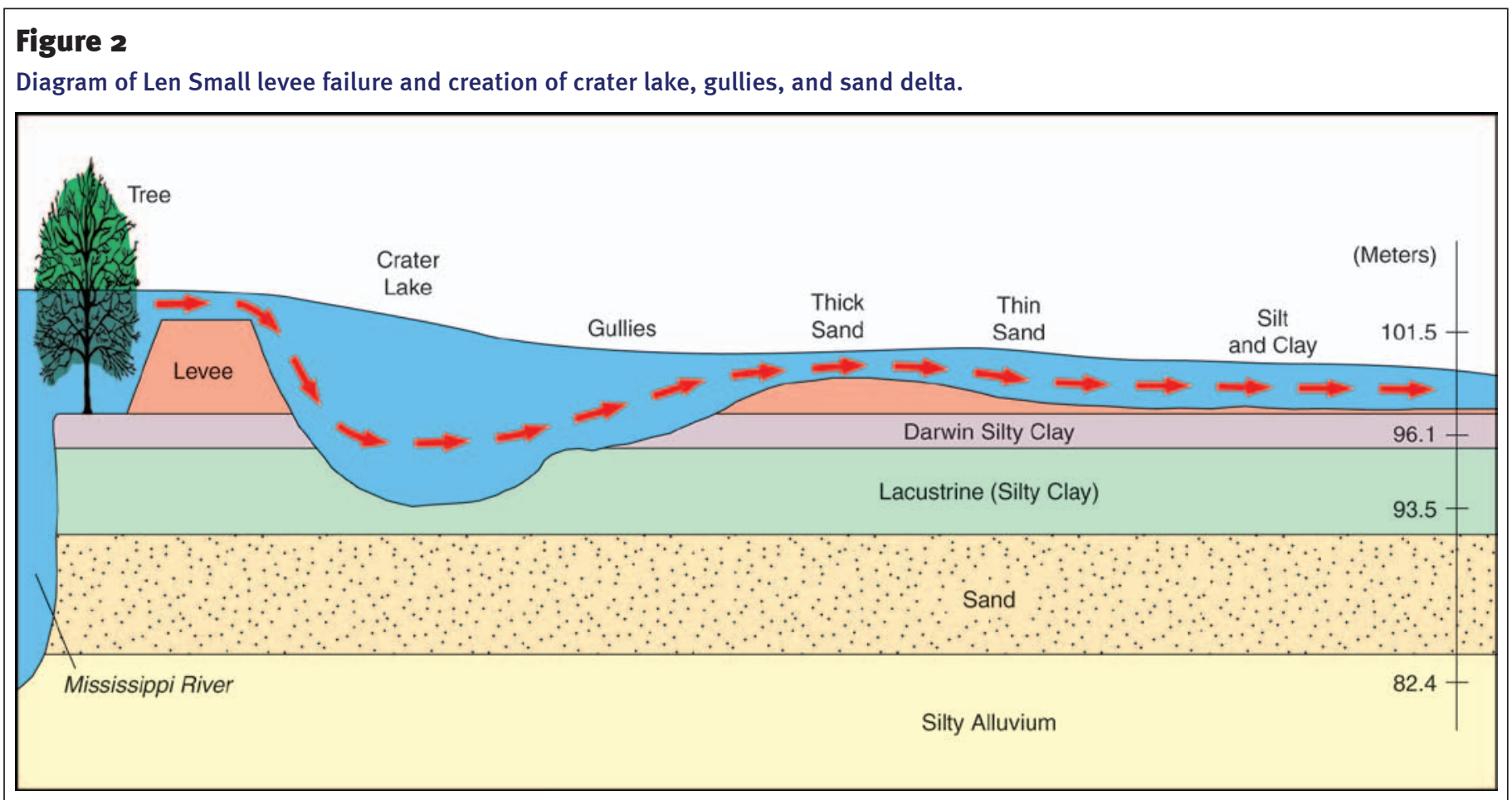

in addition to the local waters from the Cache River valley into the Mississippi River valley. Historically, the region has been a delta, confluence and bottomlands dating back 30,000 to 800,000 years B.P., with many of the Illinois lands shown on the maps located on both sides of the Upper Mississippi River as its channel changed locations over time. As a result, the fertile farmland of western Alexander County soils formed in alluvial and lacustrine deposits.

Horseshoe Lake (figure 3), a former oxbow and remnant of a large meander of the Mississippi River, is now a state park of 4,080 ha (10,200 ac) (Illinois DNR 2012). This oxbow lake, formerly a wide curve in the river, resulted from continuous erosion of its concave banks and soil deposition on the convex banks. As the land between the two concave banks narrowed, it became an isolated body of water cutoff from the main river stem through lateral erosion, hydraulic action, and abrasion. With $31 \mathrm{~km}$ $(20 \mathrm{mi})$ of shoreline, the $1.3 \mathrm{~m}(4 \mathrm{ft})$ deep lake is the northernmost natural range for Bald cypress (Taxodium distichum L.) and Tupelo (NYssa L.) trees (figure 3) and has an extensive growth of American lotus (Nelumbo lutea), a perennial aquatic plant, and native southern hardwoods which

\section{Figure 3}

The bald cypress trees and American lotus at Horseshoe Lake conservation area.

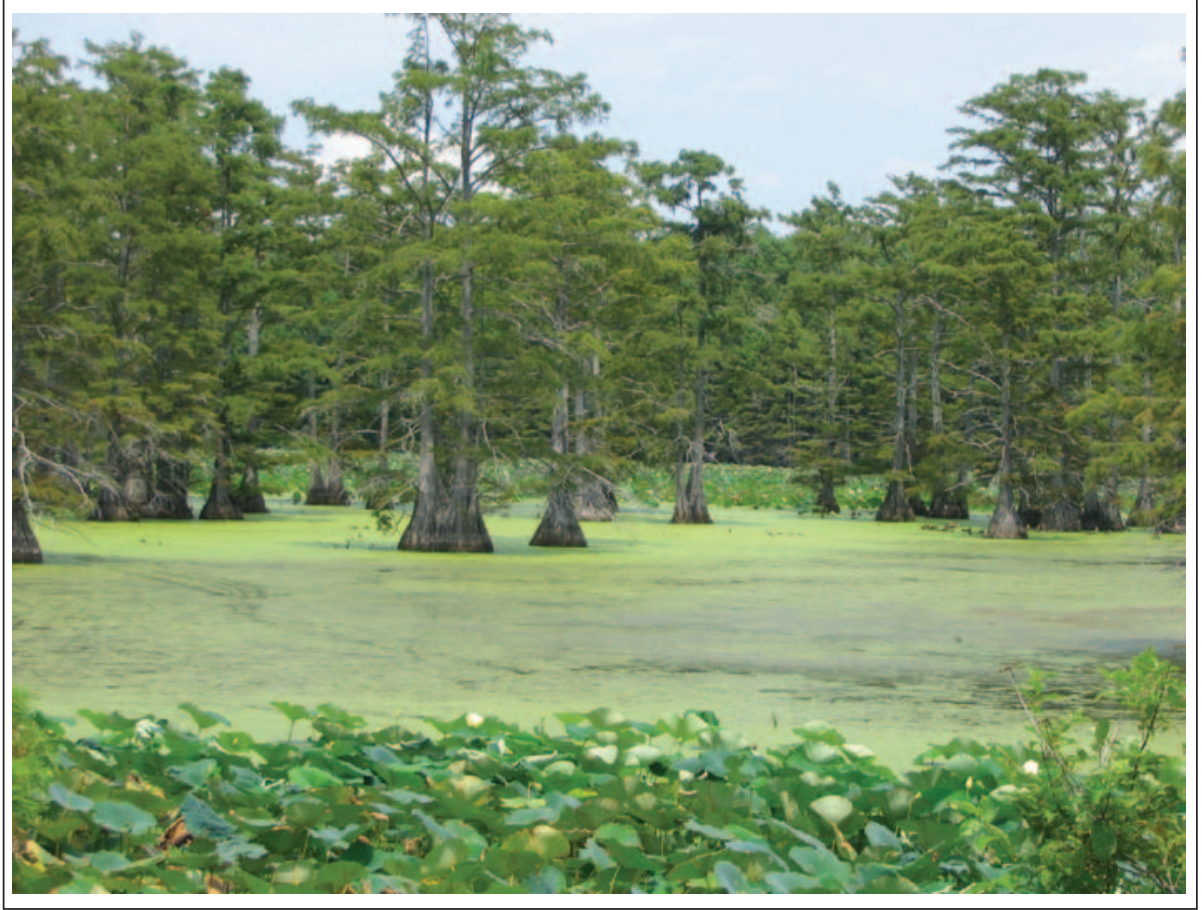

grow well in lowlands and areas which are subject to seasonal flooding.

The agricultural lands which surround this oxbow lake are highly productive alluvial soils — mostly Weinbach silt loam, Karnak silty clay, Sciotoville silt loam, and Alvin fine sandy loam. Almost two- thirds of the area $(16,000$ ha $[40,000 \mathrm{ac}])$ protected by the Len Small and Fayville levees is privately owned. Corn (Zea mays L.), soybeans (Glycine max L.), and wheat (Triticum L.) are the primary crops, with some rice (Oryza sativa L.) grown in this area. 


\section{THE COMMERCE TO BIRDS POINT, CAIRO, AND WESTERN ALEXANDER COUNTY LEVEES}

In early May of 2011, the floodwaters at the Ohio River flood gage in Cairo, Illinois, had reached $18.7 \mathrm{~m}$ (61.7 ft) (NOAA 2012). The Ohio River was $6.7 \mathrm{~m}(22 \mathrm{ft})$ above flood stage and had been causing a back-up in the Mississippi River floodwater north of the Cairo confluence prior to the USACE opening of the Birds Point-New Madrid Floodway. For more than a month, the Mississippi River back-up placed significant pressure on the Len Small and Fayville levees (figure 1). As a result, approximately $1,500 \mathrm{~m}(5,000 \mathrm{ft})$ of the Len Small levee was breached (figure 2) near mile marker 29 (figure 1) on the morning of May 2, 2011.

The flood protection offered by the Len Small and Fayville levees is important to the landowners, homeowners, and farmers in southwestern Alexander County, Illinois. However, the Len Small and Fayville levees are not the mainline levees which control the width and height of the Mississippi River. The controlling mainline levees are the frontline Cairo levee located in Illinois (Olson and Morton 2012a) and the Commerce to Birds Point levee in Missouri (figure 4). These two frontline levees, by design, are much higher and stronger than the Len Small and Fayville levees. The Len Small and Fayville levees were built by the local levee district and are not part of the Mississippi River and Tributaries project for which USACE has responsibility (figure 5). The Cairo levee has a height of 19.4 m (64 ft), or 101.4 m (334.5 ft) above sea level, and levee failure would destroy the City of Cairo. The frontline Commerce to Birds Point levee has a height of $19.8 \mathrm{~m}$ $(65.5 \mathrm{ft})$, and its failure would result in more than 1 million ha (2.5 million ac) of agricultural bottomlands in Missouri Bootheel and Arkansas on west side of the Mississippi River being flooded (figure 5). Commerce to Birds Point levee connects to a setback levee on the west side of the Birds PointNew Madrid Floodway, which extends the protection another $51 \mathrm{~km}(33 \mathrm{mi})$ to the south where it joins the frontline levee at New Madrid, Missouri, further extending the protection of the Bootheel bottomlands (Camillo 2012; Olson and Morton, 2012a, 2012b, 2013). The failure of the Hickman

\section{Figure 4}

The Commerce to Birds Point mainline US Army Corps of Engineers levee.

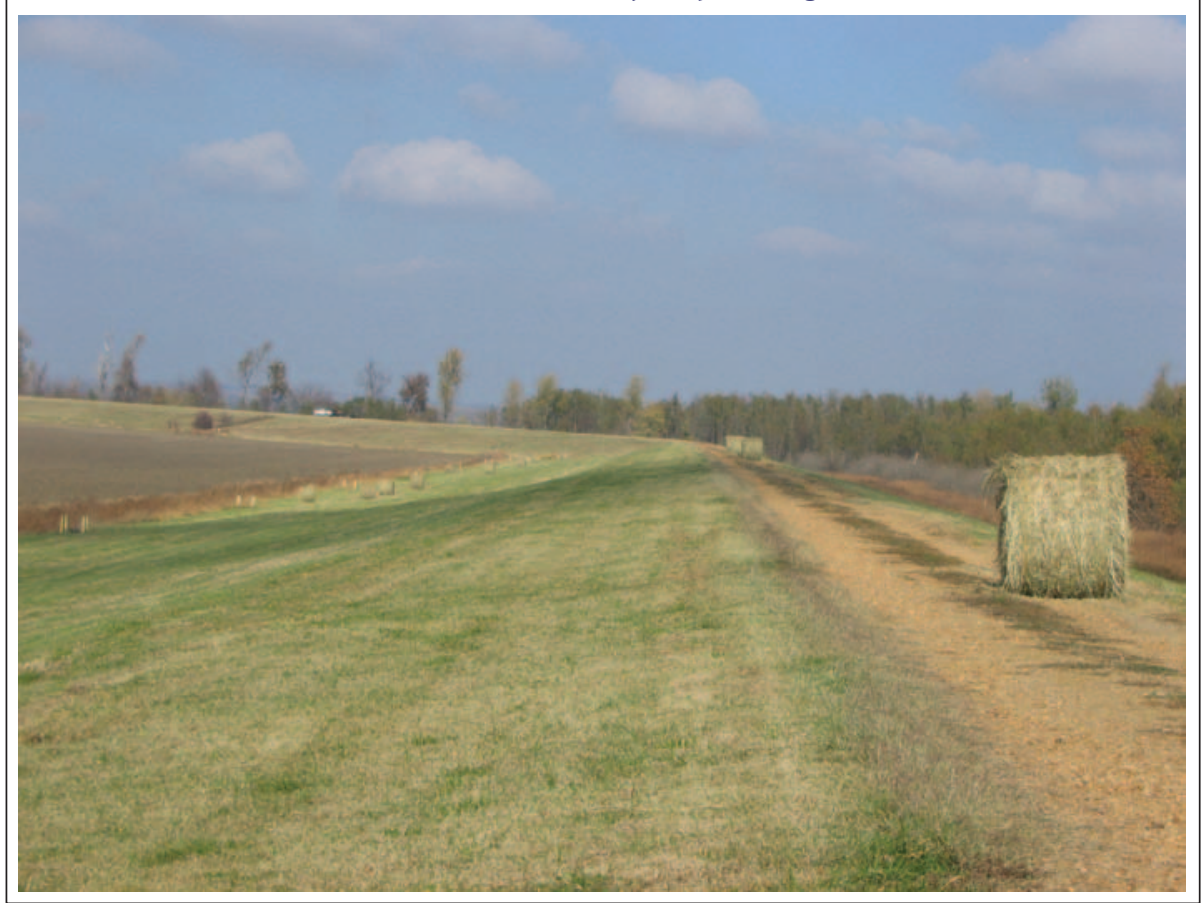

(Kentucky) levee on the east side of the Mississippi River would have resulted in the flooding of 70,000 ha $(170,000 \mathrm{ac})$ of protected bottomlands in Tennessee and Kentucky (figure 5). The floodwater height and pressure on the Commerce to Birds Point and Birds Point to New Madrid levees has increased over the years during Mississippi River flooding events with the construction of the Len Small and Fayville levees and with a strengthening of the levee near Hickman, Kentucky, which had the effect of narrowing the Mississippi River Floodway corridor and removing valuable floodplain storage areas for floodwaters.

\section{THE MISSISSIPPI RIVER COMMISSION AND ITS ROLE IN LEVEE CONSTRUCTION ALONG THE MISSISSIPPI RIVER AND TRIBUTARIES}

The Mississippi River Commission (MRC) was established by Congress in 1879 to combine the expertise of the USACE and civilian engineers to make the Mississippi River and tributaries a reliable shipping channel and to protect adjacent towns, cities, and agricultural lands from destructive floods (Camillo 2012). The Mississippi River Commission has a seven-member governing body. Three of the officers are from the USACE, including the chairman who is the final decision maker when it comes to decisions like opening the floodways. Another member is an Admiral from National Oceanic and Atmospheric Administration (NOAA), and the other three members are civilians, with at least two of the civilian members being civil engineers. Each member is appointed by the President of the United States. Senate confirmation is no longer necessary. The MRC is the lead federal agency responsible for addressing the improvement and maintenance of the Mississippi River and Tributaries project, including flow and transportation systems.

Between 1899 and 1907, MRC assisted local levee districts in Missouri with conPoint, Missouri, and Dorena, Illinois. At that time, the MCR jurisdiction was limited to the areas below the confluence of the Ohio and Mississippi rivers (Camillo 2012; Olson and Morton 2012a, 2012b), which is at the southern tip of Illinois (Fort Defiance State Park). This levee is located approximately where the current frontline levee of the Birds Point-New Madrid Floodway was constructed between 1928 and 1932 after Birds Point to Dorena levee failed in 1927.

In 1902, the MRC helped Kentucky construct a levee from the Hickman, struction of a federal levee between Birds 


\section{Figure 5}

The bottomlands in Missouri and Arkansas protected by the Commerce to Birds Point mainline levee and bottomlands in Tennessee and Kentucky protected by the Hickman levee.

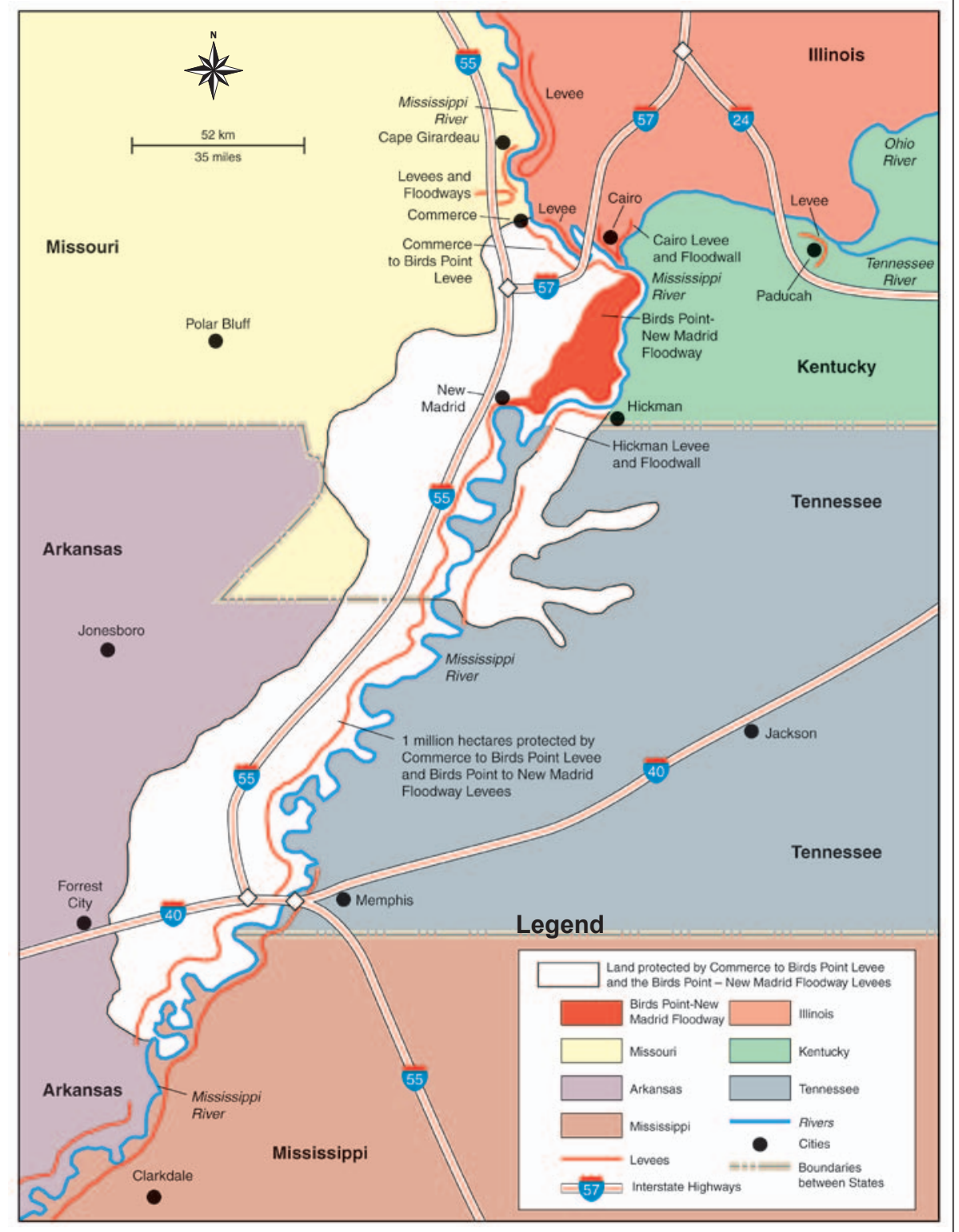

Kentucky, bluff to Tennessee, where it connected with another levee to extend the levee system $7.8 \mathrm{~km}(5 \mathrm{mi})$ to Slough Landings, Tennessee. During this time period, a portion of the natural floodplain near Cape Girardeau was walled off by a local Missouri levee to provide protection of farmland adjacent to the river (figure 1). These two levees narrowed the river channel and during high-water events on the Mississippi River increased floodwater back-up, placing tremendous pressure on the existing systems of levees and floodwalls above and below the Cairo confluence (Camillo 2012; Olson and Morton 2012a, 2012b).

The Commerce to Birds Point levee (figure 5) has long been considered by the MRC and the USACE to be the most critical levee in the Mississippi River valley since it protects nearly 1 million ha (2.5 million ac) of prime agricultural bottomlands in Arkansas and Missouri Bootheel. The Commerce to Birds Point levee, shown in figures 1 and 4, had two major threats (1973 and 1993) from past major flooding events. During the 1973 flood, a $455 \mathrm{~m}(1,500 \mathrm{ft})$ section of the
Commerce to Birds Point levee fell into the Mississippi River. The caving extended to the top of the levee. The USACE Memphis District placed 21,600 t (18,000 tn) of riprap stone carried in by barges to prevent additional caving (Camillo 2012). The Len Small levee on the Illinois side of the Mississippi River (figure 1) and across from the Commerce to Bird Point levee, Missouri, had historically overtopped or failed during larger flooding events, thereby reducing the pressure on the Commerce to Birds Point levee. The local levee and drainage district and owners of the Len Small levee strengthened their levee during the 1980s, which increased pressure on the Commerce to Birds Point levee when the river flooded. As a result, in the 1993 flood event, the Len Small levee held and the Mississippi remained confined as it climbed to within $1 \mathrm{~m}$ (3 $\mathrm{ft}$ ) of the top of the Commerce to Birds Point levee. Sand boils developed in the Commerce levee were treated until the underseepage stabilized. In 1995, USACE Memphis District raised the height and strengthened the Commerce to Birds Point levee and installed relief wells.

\section{LOCAL AND MISSISSIPPI RIVER FLOODING OF FARMLAND AND TOWNS LOCATED IN WESTERN ALEXANDER COUNTY}

The 2011 flood and record peak on the Ohio River caused the Mississippi River near the confluence to back up for many kilometers to the north and affected all bottomlands in Alexander County, Illinois, that were located on the east side of Upper Mississippi River (figure 1). Since the gradient on the Mississippi River is between 12 and $25 \mathrm{~cm} \mathrm{~km}^{-1}$ (0.5 to $1 \mathrm{ft} \mathrm{mi}^{-1}$ ), the Mississippi River water rose an additional $5.5 \mathrm{~m}(18 \mathrm{ft})$ above the flood stage further north. This occurred at a time when the Ohio River was $6.7 \mathrm{~m}(22 \mathrm{ft})$ above flood stage and the Mississippi River north of Cape Girardeau, Missouri, was 3 m $(9.9$ $\mathrm{ft})$ above flood stage. Cities farther to the north like St. Louis, Missouri, were only subjected to floodwaters $2 \mathrm{~m}$ (6.6 ft) above flood stage as a result of water flowing from the Upper Mississippi and Missouri rivers.

The May 2nd topping and breach of the Len Small levee occurred just a few 
hours before the pressure of record flood levels was relieved with the opening of the Birds Point-New Madrid Floodway at 10:00 p.m. Illinois farmers, landowners, and homeowners protected by the Len Small levee might have benefited if the floodway had been opened on April 28th or 29th (2011) when the first weather forecast was issued with a projected Ohio River peak level of $18.3 \mathrm{~m}$ (60.5 ft) or higher on the Cairo gage. This is the criteria set in 1986 USACE operational plan that needs to be met before the USACE can artificially breach the levee at Birds Point and use New Madrid Floodway to relieve river pressure and store excess floodwaters. There were a number of reasons why the USACE did not open the floodway on April 28, 2011, and waited until the evening of May 2, 2011. These reasons included the possibility that the forecasted peak would never happen and concern about the damage it would have caused to the 53,200 ha $(133,000 \mathrm{ac})$ of farmland and buildings in the Birds PointNew Madrid Floodway. Consequently, the USACE continued to monitor the situation and waited a few more days before making the final decision to load the trinitrotoluene (TNT) (once loaded it would be difficult to remove if not exploded) into the Birds Point fuse plugs and blow it up on May 2, 2011 (Camillo 2012). The other reasons for the delay were the mega sand boil in Cairo, the heavy local rains in the area of the confluence of the Ohio and Mississippi rivers, and the new peak forecast of $19.2 \mathrm{~m}$ (63.5 ft) (Camillo 2012). All these events occurred on May 1, 2011, the day the Supreme Court rejected the Missouri Attorney General's lawsuit filed in an attempt to block the USACE from opening the Birds Point-New Madrid Floodway in an effort to protect Missouri citizens and property.

Flooding of Alexander County from the Ohio and Cache rivers resulted in some flooding in the town of Olive Branch in late April and on May 1, 2011. This was before the Len Small breach occurred on May 2, 2011, and there was some damage to private and public lands prior to the breach. Floodwater from the Mississippi River added to the local flooding caused by the middle Cache River in late April

\section{Figure 6}

Land scouring, gullies, and erosion north of the Len Small levee breach.

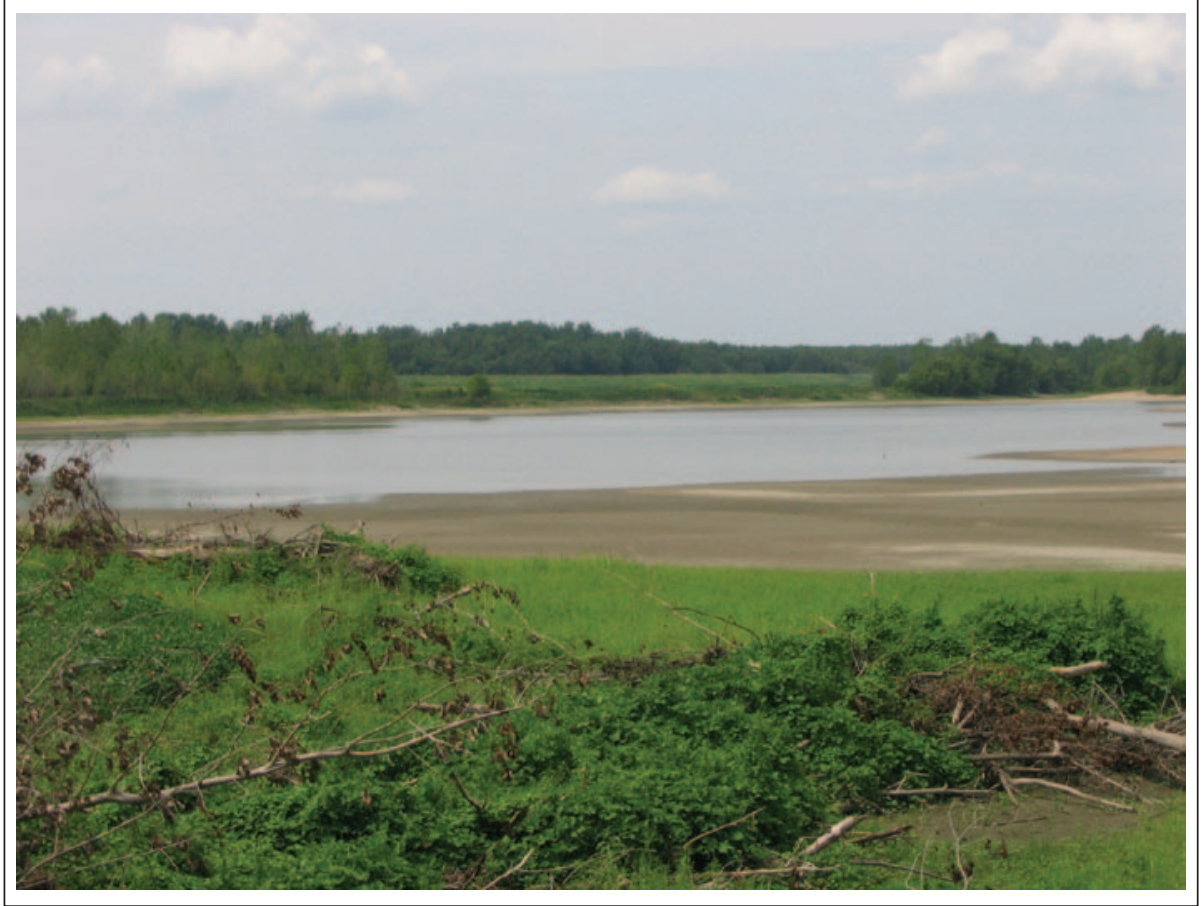

when the record high Ohio River returned to its historic path and poured through the 2002 unrepaired Karnak levee breach into the middle Cache River valley and flooded the Olive Branch and Horseshoe Lake area These floodwaters eventually drained back into the Mississippi River near Route 3 and through the diversion near mile marker 15 (figure 1) and through the Len Small levee breach.

As a result of Cache River valley floodwater flowing through the Karnak levee breach and the additional Mississippi River floodwaters pushing through the Len Small breach, 4,000 ha $(10,000 \mathrm{ac})$ of farmlands lost the winter wheat crop or were not planted in 2011, and about half of that land (mostly Weinbach silt loam, Karnak silty clay, Sciotoville silt loam, and Alvin fine sandy loam) (Parks and Fehrenbacher 1968) had significant soil damages, including land scouring and sediment deposition, or was slow to drain. Crater lakes, land scouring (figure 6), gullies, and sand deltas were created when the Len Small levee breached and removed agricultural land from production (Olson 2009; Olson and Morton 2012b). Most of the other farmland in Alexander County dried out sufficiently to permit planting of wheat in fall of 2011 It appears that all of Alexander County soils dried sufficiently by spring of 2012 to allow the planting of corn and soybeans. It is not clear how much 2011 farm income replacement came from flood insurance since not all Alexander County, Illinois, farmers had crop insurance. In addition, roads and state facilities were impacted by floodwaters which passed through the Len Small breach.

Illinois agricultural statistics recorded that 1,800 fewer ha $(4,500 \mathrm{ac})$ of corn and 2,600 less ha $(6,500 \mathrm{ac})$ of soybeans were harvested in Alexander County in 2011 compared to 2010. The area produced $1,570,000 \mathrm{bu}$ of corn in 2010 but only $710,000 \mathrm{bu}$ in 2011 . The soybean production level was 1,200,000 bu in 2010 but dropped to 865,000 bu in 2011 due to flooding, crop, and soil damage. The floodwaters also scoured the agricultural lands in some places and deposited sand at other locations.

\section{FLOODING OF PUBLIC AND PRIVATE BOTTOMLANDS WITH AND WITHOUT LEVEE PROTECTION IN WESTERN ALEXANDER COUNTY, ILLINOIS}

All bottomlands north of the confluence between the Mississippi River and the western Alexander County levees with an elevation of less than $100.7 \mathrm{~m}$ 
(332 ft) above sea level were flooded when the Mississippi River backed up. Approximately 24,000 ha $(60,000$ ac $)$ of public and private alluvial lands, both levee protected and without levees, were flooded along the east and north sides of the Mississippi River (figure 1) between mile markers 12 and 39. The 1957 to 1963 soil maps of the area show alluvial soils consisting of recently deposited sediment that varies widely in texture (from clay to sand) with stratified layers. The natural vegetation on these alluvial bottomlands ranges from recent growth of willows (Salix L.) and other plants to stands of cottonwood (Populus deltoides L.), sycamore (Platanus occidentalis L.), and sweet gum (Liquidambar styraciflua L.).

The map (figure 1) shows the public and private lands of the southwest Alexander County, Illinois, area that were impacted by the flood of 2011 . Approximately one third of the area $(8,000$ ha $[20,000 \mathrm{ac}])$ is in public lands, including uplands (the Shawnee National Forest and Santa Fe Hills) and bottomlands (Burnham Island Conservation, Horseshoe State Conservation area, Goose Island, Big Cypress, and the land adjacent to the Len Small and Fayville levees). The unleveed bottomlands and public conservation areas sustained flood damage but were more resilient than the private agricultural and urban lands inside the levees. The Mississippi bottomlands are riparian forests (transition ecosystems between the river and uplands) with fertile, fine textured clay or loam soils that are enriched by nutrients and sediments deposited during flooding (Anderson and Samargo 2007). Bottomlands that experience periodic flooding have hydrophytic plants and hardwood forests that provide valuable habitat for resident and migratory birds. The Illinois Department of Natural Resources has an extensive research program monitoring migratory birds and waterfowl at Horseshoe Lake. Although these alluvial river bottomland species are well adapted to periodic flood cycles which can last several days to a month or more (Anderson and Samargo 2007), the impact of the 2011 flood duration (2 to 4 weeks) on these wetlands habitat and woodlands has not been assessed.

\section{Figure 7}

A farmstead protected by a farmer-built levee.

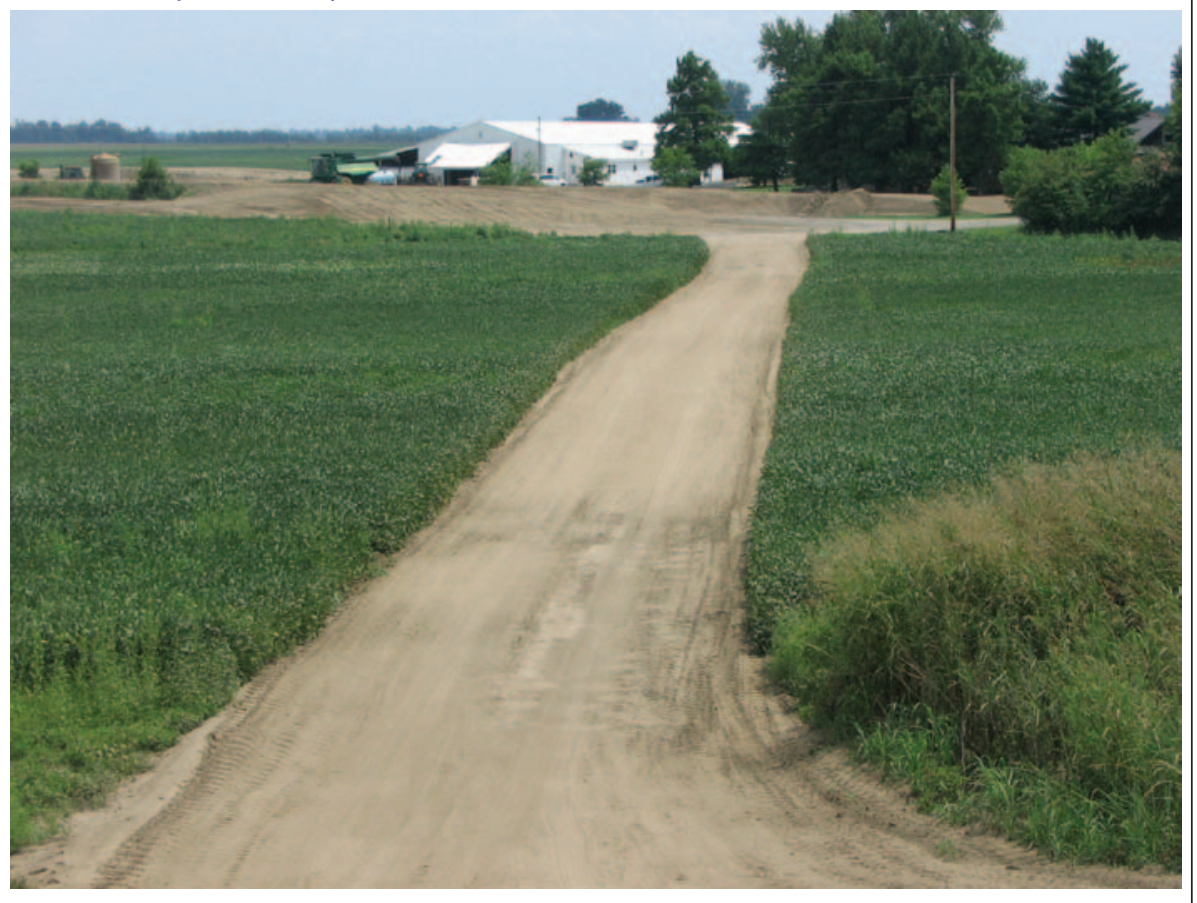

There are a number of towns and villages in western Alexander County, including Olive Branch, Miller City, and Cache. Floodwaters covered roads and railroads and damaged some bridges, homes, and other building structures. In western Alexander County, floodwater destroyed 25 Illinois homes and damaged an additional 175 homes and building structures located on Wakeland silt loam and Bonnie silt loam soils (Parks and Fehrenbacher 1968) or similar alluvial floodplain soils. The Olive Branch area (figure 1) was one of the hardest hit according to Illinois Emergency Management Agency.

Agricultural and forest lands on the riverside of the Len Small levee are not protected from flooding and store significant amounts of floodwater with minimal damage to the crops such as soybeans, which can be planted later in the spring or early summer. This farmland was under water prior to planting for the entire months of April and May, 2011. After both the Ohio and Mississippi rivers dropped and drained by late June of 2011, these fields were planted to soybeans. Late May and early June is the normal planting time for soybeans in the area, so a small soybean yield reduction was noted.

\section{REPAIR OF LEN SMALL LEVEE IN WESTERN ALEXANDER COUNTY}

In the fall of 2011, local farmers and members of the Len Small Levee District patched the Len Small levee. They cre-

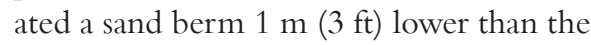
original levee. They hoped the USACE would cover the levee with a clay cap and restore it at least to the original height. The USACE agreed to do this in August of 2012 after receiving additional funds from Congress. The project was completed in 90 days. Some individual farmers created berms around their farmsteads (figure 7) to protect their farmsteads from any future flooding that might occur.

In June of 2012, the USACE received US\$802 million in emergency Mississippi River flood-repair funding for up to 143 high-priority projects to repair levees, fix river channels, and repair other floodcontrol projects in response to the spring of 2011 flood, which set records from Cairo, Illinois, to the Gulf of Mexico. Both the Birds Point-New Madrid Floodway levee repair and the Cairo area restoration projects were high on the list with the USACE targeting US $\$ 46$ million to repair the damage to Cairo area, including the Alexander County area flood-control systems (Camillo 2012; Olson and Morton 
2012a, 2012b). Improvements were completed throughout Alexander County, including work on pump stations, drainage systems, and small levees, some of which failed in April of 2011. These projects were funded by the county matching funds with the USACE and a combination of grants from the Delta Regional Authority and the State of Illinois (Koenig 2012). The creation of a larger drainage system running through northern Alexander and Union counties included large culverts and levees designed to better protect Illinois communities such as East Cape Girardeau, McClure, Gale, and Ware, and help keep water from collecting in lowlying bottomland areas.

\section{CONCLUSIONS}

In 2011, the record Ohio River flood resulted in the USACE blasting open the Birds Point levee fuse plug as waters reached a critical height on the Cairo gage. However, this unprecedented flood level at the confluence put tremendous pressure on and under the Mississippi levees to the north in western Alexander County. The delay in the decision to blow up the Birds Point fuse plugs and frontline levees had significant consequences for rural Illinois landowners, farmers, and residents in Alexander County near the Len Small levee that failed the morning of May 2, 2011, at a time when the peak flow on the Ohio River caused the Mississippi River water to back up many kilometers to the north. Local flooding and damage to building structures, crops, and soils initially occurred in late April of 2011when the Ohio River at flood stage poured through the Post Creek cutoff and a previously unrepaired Karnak levee breach and rushed to the west through the middle Cache River valley. Consequently, the town of Olive Branch would have flooded even if the Len Small breach had not occurred. The Len Small levee situation does not seem to have been a factor in the USACE decision-making process or have affected the time of the opening of the Birds Point-New Madrid levee fuse plug. The USACE did consider the need to protect the Cairo mainline levee and floodwall and the Commerce to Birds Point main line levee from a breach, as well as potential impact on landowners in the Birds Point-New Madrid Floodway. The mega sand boil in Cairo, the heavy local rains on May 1st in the Mississippi River watershed, and the new peak forecast of $19.2 \mathrm{~m}(63.5 \mathrm{ft})$ on the Cairo gage proved opening the Floodway was the correct decision. The frontline Commerce to Birds Point levee did not fail, and more than 1 million ha (2.5 million ac) of agricultural bottomlands in Missouri Bootheel and Arkansas were protected from flooding. Even if the Birds Point-New Madrid levee had been opened four days sooner at a time when the record level floodwaters were $1.3 \mathrm{~m}$ (4 ft) lower, the prolonged record Mississippi River floodwater levels and pressure on the Len Small levee, which continued for weeks, would likely have still resulted in the Len Small levee breach a few days later.

\section{ACKNOWLEDGEMENTS}

This project was funded in part by the USDA National Institute of Food and Agriculture Integrated Water Program under agreement 2008-51130-19526, Heartland Regional Water Coordination Initiative.

\section{REFERENCES}

Anderson, J., and E. Samargo. 2007. Bottomland Hardwoods. Morgantown, WV: West Virginia University, Division of Forestry and Natural Resources. http://forestandrange.org/new_wetlands/index.htm.

Camillo, C.A. 2012. Divine Providence: The 2011

Flood in Mississippi River and Tributaries Project. Vicksburg, MS: Mississippi River Commission.

Fehrenbacher, J.B., K.R. Olson, and I.J. Jansen. 1986. Loess thickness in Illinois. Soil Science 141:423-431.

Koenig, R. 2012. Corps balancing levee repairs on Missouri, Illinois sides of Mississippi. St Louis Beacon. https://www.stlbeacon.org/\#!/ content/14295/corps_balancing_levee_repairs_ on_missouri_illinois_sides_of_mississippi.

Illinois DNR (Department of Natural Resources). 2012. Horseshoe Lake. http://dnr.state.il.us/ Lands/landmgt/parks/R5/HORSHU.HTM.

NPS (National Park Service). 2012. Mississippi River Facts. http://www.nps.gov/miss/riverfacts.htm.

Nemati, K.M. 2007. Temporary Structures: Slurry Trench/Diaphragm Walls CM420. Seattle, WA: University of Washington, Department of Construction Management. http://courses. washington.edu/cm420/Lesson6.pdf.
NOAA (National Oceanic Atmosphere Administration). 2012. Historic crests. Cairo, IL: National Weather Service, Advanced Hydrologic Prediction Service.

Olson, K.R. 2009. Impacts of 2008 flooding on agricultural lands in Illinois, Missouri, and Indiana. Journal of Soil and Water Conservation 64(6):167A-171A. doi: 10.2489/jswc.64.6.167A.

Olson, K.R. and L.W. Morton. 2012a. The effects of 2011 Ohio and Mississippi river valley flooding on Cairo, Illinois, area. Journal of Soil and Water Conservation 67(2):42A-46A. doi: 10.2489/ jswc.67.2.42A.

Olson, K.R. and L.W. Morton. 2012b. The impacts of 2011 induced levee breaches on agricultural lands of Mississippi River Valley. Journal of Soil and Water Conservation 67(1):5A-10A. doi:10.2489/ jswc.67.1.5A.

Olson, K.R. and L.W. Morton. 2013. Restoration of 2011 flood-damaged Birds Point-New Madrid Floodway. Journal of Soil and Water Conservation 68(1):13A-18A. doi:10.2489/ jswc.68.1.13A.

Parks, W.D., and J.B. Fehrenbacher. 1968. Soil Survey of Pulaski and Alexander counties, Illinois. Washington, DC: USDA Natural Resource Conservation Service. 